\title{
Линейно-поляризованный гольмиевый волоконный лазер с самосканированием длины волны вблизи 2,09 мкм
}

\author{
А.Д. Владимирская ${ }^{1,2, *}$, И.А. Лобач ${ }^{1}$, С.И. Каблуков ${ }^{1}$ \\ ${ }^{1}$ Институт автоматики и электрометрии СО РАН \\ ${ }^{2}$ Новосибирский государственный технический университет \\ ${ }^{*}$ E-mail: anastasiavladimirskaya97@gmail.com
}

DOI: $10.31868 /$ RFL2020.61-62

В настоящее время особый интерес представляют источники излучения вблизи 2 мкм. В первую очередь это связано с тем, что в данной области находятся линии поглощения воды и диоксида углерода. Анализ спектрального состава данных элементов может использоваться как в биоатмосферном анализе, так и в медицине. Ранее уже было обнаружено, что по анализу изотопов диоксида углерода в выдыхаемом человеком воздухе возможно определить наличие в организме бактерий Helicobacter Pilori [1]. При проведении данного дыхательного теста измеряется относительная разница между соотношением ${ }^{13} \mathrm{C}$ и ${ }^{12} \mathrm{C}$ в исследуемой пробе и стандартным изотопным соотношением. Определение соотношения изотопов в отобранных образцах можно осуществлять лазерные спектрометры. В качестве источника для такого спектрометра может выступать перестраиваемый лазер с генерацией в области 2 мкм. Существуют различные методы обеспечения перестройки длины волны лазерной генерации. Самый распространенный метод - это использование внешних управляющих элементов, таких как дифракционные решетки, волоконные брэгговские решетки или интерферометры. Другим методом обеспечения оптической перестройки является использование эффекта самосканирования длины волны, что в волоконном исполнении было продемонстрировано менее 10 лет назад [2]. Для получения лазерной генерации в области 2 мкм можно использовать гольмиевую активную среду. Гольмиевый волоконный самосканирующий лазер с генерацией в области 2100 нм ранее был представлен в работе [3]. Однако стабильность генерации в представленной схеме нарушается под влиянием теплового и механического воздействия, что затрудняет использование данного источника для продолжительных измерений. Такая нестабильность, вероятно, связана с использованием волокна без поддержки поляризации.

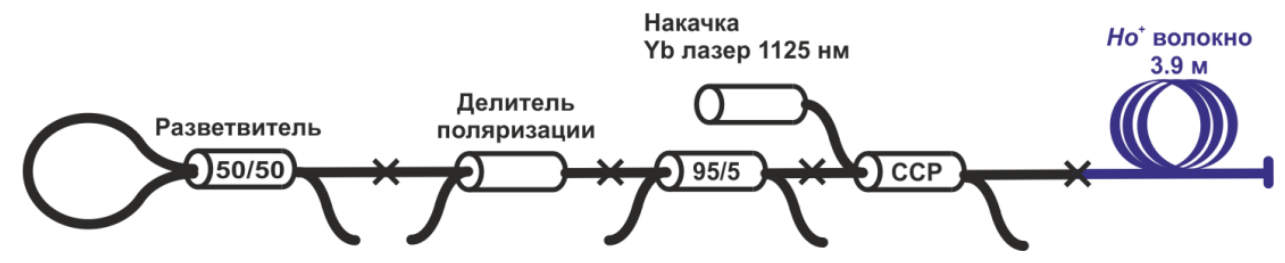

Рис. 1. Схема волоконного гольмиевого лазера с самосканированием длины волны.

Для предотвращения влияния механических деформаций на выходную генерацию в настоящей работе был реализован волоконный самосканирующий гольмиевый лазер с генерацией на основе волокна с сохранением поляризации. В качестве активного волокна использовалось 3.9 м волокна легированного ионами гольмия (IXBlue IXF-HDF-PM-8-125). Диаметр сердцевины составляет 8 мкм. Поглощение на длине волны 1125 нм составило 8,9 дБ/м. В качестве накачки выступал иттербиевый волоконный лазер с длиной волны генерации 1125 нм и 
максимальной выходной мощностью 4.8 Вт. Накачка лазера существенно отличается от работы [3], где для этих целей использовался тулиевый волоконный лазер с генераций в области 2020-2030 нм. Резонатор был образован плотным зеркалом, состоящим из разветвителя 50/50 на длине волны 2000 нм и слабоотражающим прямым сколом волокна (Рис. 1). Для эффективного заведения накачки использовался спектрально-селективный разветвитель (ССР) 1310/1960. Неидеальность параметров ССР в основном влияет на эффективность ввода излучение накачки. В схеме также присутствует делитель поляризации, который задает линейное поляризационное состояние выходного излучения. Для эффективного измерения лазерных характеристик в лазерной схеме находится разветвитель 5\%, через порты которого фиксируются измерения.

При мощности накачки от 0.75 до 1.05 Вт был получен режим обратного сканирования длины волны вблизи 2.09 нм. Область и скорость сканирования

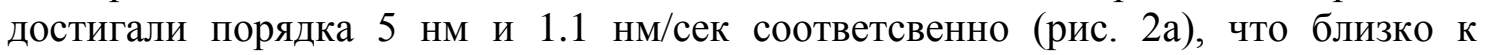
результатам работы [3] Выходная мощность генерации со стороны прямого скола достигала 150 мВт. Динамика интенсивности представляет собой квазинепрерывный сигнал, что отличается от результатов работы [3], где выходная генерация представляет собой самопульсации, которые обычно наблюдаются в режиме самоканирования длины волны. Также стоит отметить, что режим работы лазера продолжался в течении длительного времени (более 1 часа), то также отличается от работы [3], где продолжительность работы ограничивалась несколькими минутами.

Более подробное описание схемы лазера и его характеристик будет дано во время доклада. Ожидается, что разработанный перестраиваемый источник может быть использован для спектроскопии 12- и 13- изотопов диоксида углерода (рис. 2б).

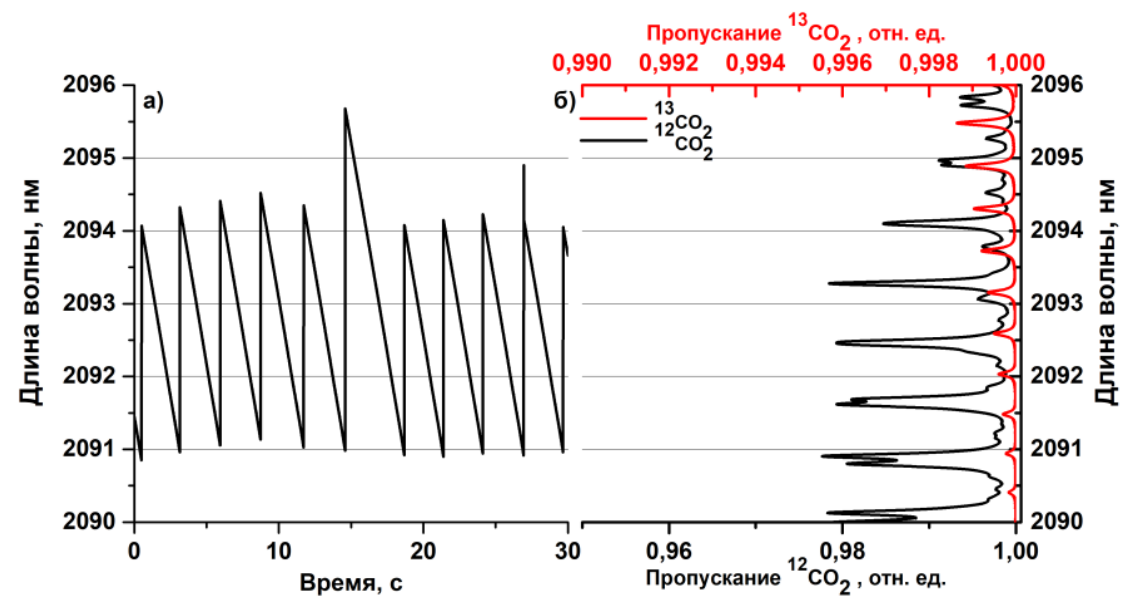

Рис. 2. Спектральная динамика лазерной генерации (а) и спектры пропускания 12- и 13- изотопов диоксида углерода (б).

Авторы выражают благодарность к.ф.-м.н. В.А. Камынину за предоставленный волоконный иттербиевый лазер накачки. Исследование было поддержано грантом РФФИ №20-32-70058.

\section{Литература}

[1] D.Y. Graham, P.D. Klein, et al, The Lancet, 329(8543), 1174-1177 (1987)

[2] I.A. Lobach, S.I. Kablukov, et al, Opt. Express 19, 17632-17640 (2011)

[3] J. Aubrecht, P. Peterka, et al, Opt. Express 25, 4120-5 (2017) 